\title{
Effects of tillage and compost amendment on infiltration in compacted soils
}

\author{
F. Mohammadshirazi, V.K. Brown, J.L. Heitman, and R.A. McLaughlin
}

\begin{abstract}
Soils are compacted during land development through soil excavation and heavy equipment traffic. Compacted soils have limited infiltration and are susceptible to erosion. Infiltration can be enhanced by various approaches including tillage and compost addition. The objective of this study was to determine the efficacy of tillage and adding compost to reduce stormwater runoff and sediment loss by improving infiltration in simulated postconstruction soils. Tillage treatments were tested at two sites in the Piedmont region of North Carolina (Piedmont 1 and 2). Prior to applying tillage and amendment, soils at both sites were graded to remove the surface horizon and compacted with a vibratory roller. At Piedmont 1, the treatments were compacted with no tillage, shallow $(15 \mathrm{~cm} \mathrm{[5.9} \mathrm{in]} \mathrm{depth)}$ tillage $(\mathrm{ST})$, and deep $(30 \mathrm{~cm}$ [11.8 in] depth) tillage (DT). At Piedmont 2 the treatments were compacted, DT, and DT with incorporated compost (DT+Com). The grass seed mixtures recommended by the North Carolina Department of Transportation for the location (Piedmont) and time of planting were applied at each site. Runoff volumes (RV) and total suspended solids were measured after each of the first 12 and 13 storm events at Piedmont 1 and 2, respectively. Infiltration rate (IR) and bulk density (BD) were determined five and seven months after establishment at Piedmont 1 and 2, respectively. At both sites, RV and total amount of soil loss were reduced with tillage by $60 \%$ to $82 \%$ during the monitoring period. Neither deeper tillage nor incorporating compost significantly affected these results. Grass establishment was significantly better with tillage. The IRs measured at the end of the monitoring period were around $1 \mathrm{~cm} \mathrm{~h}^{-1}\left(0.4 \mathrm{in} \mathrm{hr}^{-1}\right)$ in the compacted treatment but ranged from 19 to $33 \mathrm{~cm} \mathrm{~h}^{-1}$ (7.5 to $13 \mathrm{in} \mathrm{hr}^{-1}$ ) in the tilled treatments, again with no effects of tillage depth or compost. The results suggest that tillage to a depth of at least $15 \mathrm{~cm}$ (6 in) can be highly effective for improving soil conditions and reducing runoff and erosion from soils compacted as the result of construction activities.
\end{abstract}

Key words: compost—construction site—erosion—runoff—-tillage

The process of constructing roads, buildings, and other structures can result in highly disturbed areas in which the soil is compacted from vehicle and equipment traffic (Gregory et al. 2006). Soils in urban areas may be compacted purposefully to increase strength or unintentionally due to construction activities (Batey and McKenzie 2006; Gregory et al. 2006; Olson et al. 2013).

Compaction affects soil physical properties and vegetative growth (Randrup and Dralle 1997). Several studies found that compaction reduced soil porosity (Craul 1994; SchaferLandefeld et al. 2004; Shestak and Busse 2005), infiltration rate (IR) (Brown 2012; Haynes et al. 2013; Siyal 2002; Woltemade 2010; Yang and Zhang 2011), and root growth (Alberty et al. 1984; Gilman et al 1987), and this leads to increased runoff and erosion (Booth and Jackson 1997; Violin et al. 2011). Runoff from areas with compacted soil is often directed into overburdened stormwater systems and stream channels (Booth and Jackson 1997; Violin et al. 2011).

Creating an environment for deep plant root growth is important to make the plants less susceptible to drought stress and it encourages the development of channels for water infiltration (Bartens et al. 2008; Bouma and Dekker 1978; Hino et al. 1987). Kozlowski et al. (1999) showed that roots extend through existing soil pores, and when compaction decreases large pore spaces, root growth is inhibited.
Lipiec et al. (2006) showed that tillage to the depth of $20 \mathrm{~cm}$ (7.8 in) in silt loam soil affected pore size distribution; $10 \%$ of the soil volume contained large pores $(>117 \mu \mathrm{m})$ in conventional agricultural tillage, while the portion of large pores was $6 \%$ in no tillage. The cumulative infiltration using a double-ring infiltrometer on the conventionally tilled treatment for three hours was $94.5 \mathrm{~cm}$ (37.2 in), while infiltration in no-till treatments was $36 \%$ to $62 \%$ less. It may also be possible to implement tillage to improve infiltration for postconstruction soil conditions. In a compacted soil, simulating postconstruction site conditions, Haynes et al. (2013) found that tillage to 20 to $30 \mathrm{~cm}$ (7.9 to 11.8 in) depth in a Cecil sandy loam greatly improved infiltration when a vigorous stand of vegetation was established quickly.

Using soil amendments along with tillage might be a way to further improve soil physical properties and plant growth in postconstruction sites. In a study on a clay loam soil, Bazzoffi et al. (1998) found that using urban refuse compost along with tillage resulted in reduction of runoff volume (RV) and total erosion during all three years of the experiment. Improved infiltration and changes in saturated hydraulic conductivity were observed in a compost experiment by Curtis et al. (2007). In their study, compost was mixed into a highly erodible, decomposed granite saprolite soil located on a roadside cut slope at three rates: $6 \%, 12 \%$, and $24 \%$ by volume of compost to decomposed granite. Significant increases in saturated hydraulic conductivity were observed at the $12 \%$ and $24 \%$ compost rates.

Effectively managing stormwater RV is a challenge in many urban settings. The hypothesis of this study was that soil tillage and compost incorporation reduce stormwater runoff and sediment loss by improving the IR. The study results presented herein represent the first growing season after site establishment following treatment at each of two sites.

Fatemeh Mohammadshirazi and Virginia K. Brown were graduate students, Josh L. Heitman is an associate professor, and Rich A. McLaughlin is a professor in the Department of Soil Science, North Carolina State University, Raleigh, North Carolina. 


\section{Materials and Methods}

The study was conducted in the Piedmont region of North Carolina, near Raleigh, with the latitude of $35^{\circ} 44^{\prime} 9.73^{\prime \prime} \mathrm{N}$, longitude of $78^{\circ} 40^{\prime} 41.77^{\prime \prime} \mathrm{W}$, and elevation of $118 \mathrm{~m} \mathrm{(386}$ $\mathrm{ft})$. Two adjacent simulated postconstruction sites were evaluated (Piedmont 1 and 2) to study different treatments (table 1). Piedmont 1 was established in late February of 2011 and Piedmont 2 was established in late April of 2012. The sites were located on a grassed slope mapped as Cecil (Fine, kaolinitic, thermic Typic Kanhapludults) and Mantachie (Fine-loamy, siliceous, active, acid, thermic Fluventic Endoaquepts). Preparation at each site was similar. The topsoil and vegetation were removed to expose the subsoil, which meant removing $<30 \mathrm{~cm}$ to $90 \mathrm{~cm}(<12$ in to 36 in) of topsoil depending on the position on the sloped area. The area was then graded to achieve a uniform surface, with a slope of $2 \%$ to allow for some surface drainage and runoff collection. Particle size analysis was performed on the exposed subsoil using the hydrometer method (Gee and Bauder 1986). The exposed subsoil contained $48 \%$ sand, $12 \%$ silt, and $40 \%$ clay (sandy clay texture).

To simulate compaction from equipment traffic on construction sites, the graded area was further compacted by repeated passes with an $11 \mathrm{Mg}$ (12 tn), smooth drum vibratory roller to obtain a target bulk density (BD) of $1.5 \mathrm{~g} \mathrm{~cm}^{-3}\left(93.6 \mathrm{lb} \mathrm{ft}^{-3}\right)$. This is similar to the BD found on nearby construction sites (Haynes et al. 2013) and that were found in previous studies (Alberty et al. 1984; McNabb 1994; Yang and Zhang 2011), and is well into the range reported to limit root growth (Houlbrooke et al. 1997). After compaction, samples from the upper $10 \mathrm{~cm}(3.9$ in) of the soil were taken using a $6 \mathrm{~cm}(2.4$ in) diameter soil core sampler (AMS Inc., American Falls, Idaho) and analyzed for BD (Rogers and Carter 1987). The upper $2.5 \mathrm{~cm}$ (1 in) ring from each sample was discarded to avoid measuring any minor compaction caused by the sampler's hammer driver. Samples were oven dried at $105^{\circ} \mathrm{C}\left(221^{\circ} \mathrm{F}\right)$ and weighed to determine the $\mathrm{BD}$.

At Piedmont 1, the treatments were compacted with no tillage, shallow $(15 \mathrm{~cm}$ depth [5.9 in]) tillage (ST), and deep (30 cm depth [11.8 in]) tillage (DT), randomly located in four blocks. The central question here was whether the depth of tillage significantly affected infiltration and plant growth. At Piedmont 2, the treatments were compacted,
DT, and DT with incorporated compost (DT+Com), which is a commonly recommended amendment, randomly located within only three blocks due to space limitations. The compost was an erosion control blend obtained from Novozymes North America, Inc. (Franklinton, North Carolina), with a $1.2 \mathrm{~cm}$ (0.47 in) sieve size, $\mathrm{pH}$ of 7.6, and C: $\mathrm{N}$ ratio of 14.5 . A $5 \mathrm{~cm}$ (2 in) deep layer of compost was applied to the surface and incorporated during tillage. In this experiment, the central question was whether the additional expense of including compost significantly improved infiltration over tillage alone. Prior to tilling, a backhoe initially broke up the compacted soil surface to allow the tillage equipment to penetrate to the desired depths. Repeated passes using a tractor-mounted rotary tiller accomplished the tillage to the desired depth.

Prior to treatment, soil samples from the upper $10 \mathrm{~cm}$ (3.9 in) of the site were sent to the North Carolina Department of Agriculture and Consumer Services (NCDA\&CS) for analysis for lime recommendations for grass establishment. Recommended (NCDOT 2008) fertilizer $\left(560 \mathrm{~kg} \mathrm{ha} \mathrm{ha}^{-1}\left[500 \mathrm{lb} \mathrm{ac} \mathrm{la}^{-1}\right]\right.$ of 10-20-20) was mixed in during tillage, except for compacted plots where fertilizer was surface-applied. We followed the North Carolina Department of Transportation seeding recommendations and planting dates for the Piedmont region (NCDOT 2008). Mixed seed rates of $84 \mathrm{~kg} \mathrm{ha}^{-1}\left(74.8 \mathrm{lb} \mathrm{ac}^{-1}\right)$ hard fescue (Festuca trachyphylla), $22.4 \mathrm{~kg} \mathrm{ha}^{-1}$ $\left(19.9 \mathrm{lb} \mathrm{ac}^{-1}\right.$ ) Kentucky bluegrass (Poa pretensis), and $28 \mathrm{~kg} \mathrm{ha}^{-1}\left(24.9 \mathrm{lb} \mathrm{ac}^{-1}\right)$ rye grain (Secale cereal) were used at Piedmont 1, and $73.2 \mathrm{~kg} \mathrm{ha}^{-1}\left(65.1 \mathrm{lb} \mathrm{ac}^{-1}\right)$ tall fescue (Festuca arundinacea), $9.8 \mathrm{~kg} \mathrm{ha}^{-1}\left(8.7 \mathrm{lb} \mathrm{ac}^{-1}\right)$ centipedegrass (Eremochloa ophiuroides), and 29.3 $\mathrm{kg} \mathrm{ha}^{-1}\left(26.1 \mathrm{lb} \mathrm{ac}^{-1}\right.$ ) bermudagrass (Cynodon dactylon) were used at Piedmont 2. The seed was protected by temporary cover of straw with jute netting stapled on top at Piedmont 1 (this fabric was removed a few weeks after germination), and straw with a light application of hydromulch as a tackifier at Piedmont 2 (Terra Mulch, Profile Products, Chicago, Illinois; $1,100 \mathrm{~kg} \mathrm{ha}^{-1}$ [979 $\left.\left.\mathrm{lb} \mathrm{ac}^{-1}\right]\right)$. Once the grass was established, the vegetation was cut periodically either with a riding lawn mower $(1 / 2$ of plot) or a string trimmer $(1 / 2$ of plot), with the former representing minimal "traffic" and the latter "no traffic."

In order to collect runoff, a square (at Piedmont 1) or an equilateral triangle (at
Piedmont 2) subplot area was surrounded with plastic garden edging $(10 \mathrm{~cm}$ [3.9 in] high) with $1.2 \mathrm{~m}(3.9 \mathrm{ft})$ length of each side, inserted about $5 \mathrm{~cm}$ ( 2 in) into the soil (Haynes et al. 2013). The edges and gaps were sealed with expanding foam (Great Stuff, Dow Chemical Company, Wilmington, Illinois). Along the lower end of the plots, an opening was left, and a $5 \mathrm{~cm}$ (2 in) diameter PVC pipe was sealed flush with the edging with the expanding foam. Runoff water generated within the edged area exited via the pipe into a $208 \mathrm{~L}$ (54.9 gal) collection tub, located in a ditch downhill from the plot area. Assuming $100 \%$ runoff, the tub size allowed us to capture all runoff from a $36.6 \mathrm{~mm}$ (1.4 in) storm, which has a recurrence of 0.5 year for a 24 hour period in this area. To minimize precipitation from increasing RV, each tub was fitted with a lid. The vegetation inside of the runoff collection area was cut periodically with a string trimmer, so the runoff and sediment loss results represent the "no traffic" condition.

Rainfall data for a weather station adjacent to the sites were retrieved from the State Climate Office of North Carolina (http:// www.nc-climate.ncsu.edu). The weather station was located approximately $800 \mathrm{~m}(0.5$ mi) from the plots. After each storm event, RV was determined by recording the depth of water in the collection tubs and calculating the volume from a calibration curve developed by adding known amount of water and measuring the depth. Water within the tub was then mixed thoroughly to suspend sediments while a subsample was taken. These subsamples were analyzed for total suspended solids (TSS). If RV was minimal (less than 1 L [0.3 gal]), the entire sample was taken.TSS was determined by filtration (Clesceri et al. 1998) using $90 \mathrm{~mm}$ (3.5 in) glass fiber filters (ProWeigh, Environmental Express Mt. Pleasant, South Carolina).

Infiltration measurements were obtained using a Cornell Sprinkle Infiltrometer (CSI; Cornell University, Ithaca, New York) (Ogden et al. 1997) at Piedmont 1 and 2, approximately five and seven months after plot establishment, respectively. The CSI ring was inserted into the ground to a depth of $7.5 \mathrm{~cm}$ (3 in) so the runoff exit opening on the ring was flush with the ground surface. The CSI tank was then filled and placed on top of the ring; a rainfall rate between 20 and $60 \mathrm{~cm} \mathrm{~h}^{-1}$ (7.9 and 23.6 in $\mathrm{hr}^{-1}$ ) was set for each plot and allowed to run until a constant rate of runoff was achieved, which typi- 


\section{Table 1}

General summary of site characteristics and measured parameters.

\begin{tabular}{|c|c|c|c|c|c|c|}
\hline Site & Establishment & $\begin{array}{l}\text { Main tillage } \\
\text { treatments }\end{array}$ & Subtreatments & $\begin{array}{l}\text { Seed applied and } \\
\text { rate }\left(\mathrm{kg} \mathrm{ha}^{-1}\right)\end{array}$ & $\begin{array}{l}\text { Fertilizer } \\
\text { applied } \\
\left(\mathbf{k g ~ h a}^{-1}\right)\end{array}$ & $\begin{array}{l}\text { Measured parameters/time } \\
\text { after site establishment }\end{array}$ \\
\hline Piedmont 1 & $\begin{array}{l}\text { February of } \\
\text { 2011/Raleigh, } \\
\text { North Carolina }\end{array}$ & $\begin{array}{l}\text { Compacted } \\
\text { Shallow till } \\
\text { Deep till }\end{array}$ & $\begin{array}{l}\text { Traffic } \\
\text { No traffic }\end{array}$ & $\begin{array}{l}\text { Hard fescue (84.0) } \\
\text { Kentucky bluegrass (22.4) } \\
\text { Rye grain (28.0) }\end{array}$ & $\begin{array}{l}N=48.8 \\
P=97.6 \\
K=97.6\end{array}$ & $\begin{array}{l}\text { Runoff percentage/the first } 12 \text { storms } \\
\text { Sediment loss/the first } 12 \text { storms } \\
\text { Infiltration rate/five months } \\
\text { Bulk density/five months } \\
\text { Shoot mass and grass coverage/five months } \\
\text { Root mass/five months }\end{array}$ \\
\hline Piedmont 2 & $\begin{array}{l}\text { April of 2012/ } \\
\text { Raleigh, North } \\
\text { Carolina }\end{array}$ & $\begin{array}{l}\text { Compacted } \\
\text { Deep till } \\
\text { Deep till + } \\
\text { compost }\end{array}$ & $\begin{array}{l}\text { Traffic } \\
\text { No traffic }\end{array}$ & $\begin{array}{l}\text { Tall fescue (73.2) } \\
\text { Bermudagrass (29.3) } \\
\text { Centipedegrass (9.8) }\end{array}$ & $\begin{array}{l}N=48.8 \\
P=97.6 \\
K=97.6\end{array}$ & $\begin{array}{l}\text { Runoff percentage/the first } 13 \text { storms } \\
\text { Sediment loss/the first } 13 \text { storms } \\
\text { Infiltration rate/seven months } \\
\text { Bulk density/seven months }\end{array}$ \\
\hline
\end{tabular}

Notes: $\mathrm{N}=$ nitrogen. $\mathrm{P}=$ phosphorus. $\mathrm{K}=$ potassium.

cally occurred within 10 minutes. Runoff was collected in a beaker placed in a small hole dug adjacent to the ring, and volume was determined every minute. Lower rainfall rates were used on compacted treatment plots because of the rapid runoff rate in these plots. The IR was calculated from the difference between the water volume applied during the test and the volume of runoff. Correction factors, which account for horizontal water movement below the ring, were applied to all data according to the CSI manual. At the same time as CSI measurements, additional soil samples were collected from each plot to determine $\mathrm{BD}$, using an approach similar to that described above.

At Piedmont 1, vegetation sampling was done five months after site establishment and seeding (spring of 2011), when the minimum aboveground plant (shoot) height was about 5 to $10 \mathrm{~cm}$ (2 to 3.9 in). Clippings from inside three randomly selected $10 \times 10$ $\mathrm{cm}(3.9 \times 3.9$ in $)$ areas within a $1 \times 1 \mathrm{~m}$ $(3.3 \times 3.3 \mathrm{ft})$ grid placed on each plot were oven dried at $65^{\circ} \mathrm{C}\left(149^{\circ} \mathrm{F}\right)$ for 48 hours and then weighed for aboveground biomass (shoot mass) estimates (Haynes et al. 2013). Vegetative cover was estimated by taking photos from $1.1 \mathrm{~m}(3.7 \mathrm{ft})$ above each plot with an Olympus digital camera model No. TG-320 (Olympus Imaging Corp., Tokyo, Japan), then the digital plot photos were analyzed using the Geographic Information System (GIS) program ArcMap (ESRI, Redlands, California). Images were evaluated for the number of green pixels and the number of nongreen pixels to determine grass coverage. No vegetation measurements were made at Piedmont 2.
Root samples were obtained using the BD core sampler for each treatment at Piedmont 1 at approximately the same time as aboveground vegetation was measured (Vogt and Persson 1991). Samples from two different depths (0 to $15 \mathrm{~cm}$ [0 to $5.9 \mathrm{in}$ ] and 15 to $30 \mathrm{~cm}$ [5.9 to $11.8 \mathrm{in}])$ were removed for root sampling. The samples were washed to remove the soil from the roots under a steady stream of water using a $1.7 \mathrm{~mm}$ (0.07 in) US standard testing sieve (ASTM E-11 specification, Fisher Scientific Company, Chicago, Illinois). The roots were placed in a paper envelope and oven dried for 48 hours at a temperature of $65^{\circ} \mathrm{C}\left(149^{\circ} \mathrm{F}\right)$. After 48 hours the samples were removed from the oven and equilibrated for few hours to reach room temperature and then weighed.

SAS Software was used to perform all statistical analyses (SAS version 9.1, SAS Institute, Cary, North Carolina). Analysis of variance (ANOVA) using the PROC MIXED procedure was performed on all data. In both sites, the level of main plots (tillage) arranged in a randomized complete block design (RCBD) and the level of subplot (traffic) arranged in a split-plot design. The defined error terms for each level of analysis were the following: "main plots $\times$ replication" as error term for analyzing the effect of main plots, and "subplot $\times$ replication (main plot)" as error term for analyzing the effect of subplot. When treatment effects were found significant with F test, means were separated by the least significant difference (LSD) test at $p=0.05$ When there was no significant effect for any subtreatments, their data were combined with the main treatment in the table.

\section{Results and Discussion}

Runoff Volume. At Piedmont 1, runoff was less for ST than compacted in 7 of 12 storms, and DT had less runoff for all 12 storms compared to compacted (table 2). Treatment DT had less runoff compared to ST in four events, of which two of these were events with the largest rainfall amounts. This generally supports the idea that deeper tillage can provide greater capacity to infiltrate rainfall and reduce runoff (Haynes et al. 2013), but that the benefit may only occur for large storms. Over the course of the first 12 storms, almost a third of rainfall ran off the compacted soil, and this was reduced by more than $82 \%$ with the tillage treatments. Haynes et al. (2013) found this reduction to be $84 \%$ in DT compared to compacted treatment.

At Piedmont 2, both tillage treatments resulted in reduced runoff in 12 of 13 storms, but there were no significant differences in runoff rates between DT and DT+Com (table 3). Up to $81 \%$ of rainfall in individual storms ran off of the compacted treatment, while in all but the first storm less than 10\% left the tilled treatments. The overall reduction in RV due to tillage was similar to Piedmont 1 , with about $83 \%$ less runoff compared to the compacted treatment.

In general, statistical trends between RV and storm total rainfall were weak, likely due to variability in storm duration and soil moisture conditions. There were also no clear relationships between runoff rates and peak rainfall intensity, similar to the findings of Parsons and Stone (2006). However, for both sites, there was clearly a large reduction in RV in the tilled treatments. Isikwue et al. (2010) also reported a significant reduction in $\mathrm{RV}$ in the tilled compared to untilled treatments. 
Table 2

Rainfall, peak intensity, runoff, and sediment loss at Piedmont 1 for 12 storms that generated runoff immediately after establishment. The site was established in late February of 2011.

\begin{tabular}{|c|c|c|c|c|c|c|c|c|c|c|c|c|c|}
\hline \multirow[b]{2}{*}{ Variable } & \multicolumn{13}{|c|}{ Storm date (2011) } \\
\hline & Mar. 6 & Mar. 9 & Mar. 26 & Apr. 5 & Apr. 9 & Apr. 16 & Apr. 28 & May 4 & May 14 & May 31 & June 20 & June 27 & Total \\
\hline Precipitation (mm) & 22 & 14 & 9 & 11 & 33 & 16 & 13 & 12 & 19 & 30 & 15 & 51 & 245 \\
\hline $\begin{array}{l}\text { Peak storm } \\
\text { intensity }\left(\mathrm{mm} \mathrm{h}^{-1}\right)\end{array}$ & 12 & 3 & 2 & 6 & 11 & 11 & 8 & 4 & 17 & 19 & 11 & 42 & - \\
\hline \multicolumn{14}{|c|}{ Runoff for different treatments (\% of rainfall) } \\
\hline Compacted & $22 \mathrm{a}$ & $8 a$ & $32 a$ & $26 a$ & $76 a$ & $61 a$ & $19 a$ & $6 a$ & $57 a$ & $26 a$ & $6 a$ & $40 a$ & $32 a$ \\
\hline Shallow till & $0.6 b$ & $2 b$ & $17 a$ & $5 a$ & $13 b$ & $6 b$ & $3 b$ & $2 a b$ & $9 b$ & $6 a b$ & $2 a b$ & $13 b$ & $7 b$ \\
\hline Deep till & $1 b$ & $1 b$ & $2 b$ & $1 b$ & $2 c$ & $3 b$ & $2 b$ & $1 b$ & $4 b$ & $3 b$ & $2 b$ & $3 c$ & $4 b$ \\
\hline \multicolumn{14}{|c|}{ Sediment loss for different treatments $\left(\mathrm{kg} \mathrm{ha}^{-1}\right)$} \\
\hline Compacted & $37 a$ & $3 a$ & $134 a$ & $16 a$ & $158 a$ & $71 a$ & $25 a$ & $14 a$ & $89 a$ & $94 a$ & $40 a$ & $288 a$ & $969 a$ \\
\hline Shallow till & $46 a$ & $2 a b$ & $5 a$ & $21 a$ & $57 a$ & $31 b$ & $31 a$ & $10 a b$ & $13 b$ & $19 b$ & $7 b$ & $103 b$ & $345 b$ \\
\hline Deep till & $45 a$ & $1 b$ & $11 a$ & $10 b$ & $53 a$ & $16 \mathrm{~b}$ & $14 a$ & $6 b$ & $14 b$ & $19 b$ & $10 b$ & $26 b$ & $225 b$ \\
\hline
\end{tabular}

Note: Means followed by the same letter within a column are not statistically different ( $p=0.05)$.

Table 3

Rainfall, peak intensity, runoff, and sediment loss at Piedmont 2 for 13 storms that generated runoff immediately after establishment. The site was established in late April of 2012.

\begin{tabular}{|c|c|c|c|c|c|c|c|c|c|c|c|c|c|c|}
\hline \multirow[b]{2}{*}{ Variable } & \multicolumn{14}{|c|}{$\underline{\text { Storm date (2012) }}$} \\
\hline & May 5 & May 9 & May 14 & May 17 & June 22 & July 10 & July 11 & July 20 & July 23 & July 28 & Aug. 7 & Aug. 22 & Sept. 3 & Total \\
\hline Precipitation (mm) & 33 & 18 & 16 & 13 & 14 & 16 & 18 & 17 & 19 & 23 & 16 & 9 & 34 & 245 \\
\hline $\begin{array}{l}\text { Peak storm } \\
\text { intensity }\left(\mathrm{mm} \mathrm{h}^{-1}\right)\end{array}$ & 14 & 15 & 5 & 12 & 6 & 12 & 10 & 4 & 18 & 22 & 12 & 8 & 23 & - \\
\hline \multicolumn{15}{|c|}{ Runoff for different treatments (\% of rainfall) } \\
\hline Compacted & $51 a$ & $61 a$ & $45 a$ & $81 a$ & $1 a$ & $5 a$ & $22 a$ & $27 a$ & $14 a$ & $25 a$ & $21 a$ & $36 a$ & $30 a$ & $33 a$ \\
\hline Deep till & $11 b$ & $6 b$ & $5 b$ & $4 b$ & $1 a$ & $1 b$ & $2 b$ & $1 b$ & $2 b$ & $9 b$ & $2 b$ & $5 b$ & $5 b$ & $5 b$ \\
\hline $\begin{array}{r}\text { Deep till + } \\
\text { compost }\end{array}$ & $13 b$ & $7 \mathrm{~b}$ & $3 b$ & $4 b$ & $1 \mathrm{a}$ & $1 \mathrm{~b}$ & $2 b$ & $2 b$ & $3 b$ & $9 b$ & $4 \mathrm{~b}$ & $8 b$ & $7 \mathrm{~b}$ & $6 b$ \\
\hline \multicolumn{15}{|c|}{ Sediment loss for different treatments $\left(\mathrm{kg} \mathrm{ha}^{-1}\right)$} \\
\hline Compacted & $53 a$ & $37 a$ & $44 a$ & $194 a$ & $1 b$ & $12 a$ & $31 a$ & $15 a$ & $27 a$ & $48 a$ & $12 a$ & $8 a$ & $20 a b$ & $502 a$ \\
\hline Deep till & $17 b$ & $12 a$ & $7 b$ & $18 b$ & $3 a$ & $6 a$ & $3 a$ & $1 b$ & $9 a$ & $19 a$ & $5 a$ & $9 a$ & $11 b$ & $120 b$ \\
\hline $\begin{array}{r}\text { Deep till + } \\
\text { compost }\end{array}$ & $21 b$ & $15 a$ & $2 b$ & $24 b$ & $1 a b$ & $6 a$ & $5 a$ & $2 b$ & $15 a$ & $48 a$ & $8 a$ & $17 a$ & $38 a$ & $202 b$ \\
\hline
\end{tabular}

Note: Means followed by the same letter within a column are not statistically different $(p=0.05)$.

Erosion (Sediment Loss). At Piedmont 1 , sediment loss was less for ST than compacted in 5 of 12 storms, and DT had less sediment loss in 8 of 12 storms compared to compacted (table 2). There were no statistical differences between the two tillage treatments except for one storm, although DT generally had numerically lower total sediment loss values than ST. Total sediment loss was reduced by ST and DT treatments by $64 \%$ and $77 \%$, respectively, compared to the compacted treatment. Most of the differences occurred later in the season, perhaps as a result of improved grass growth on the tilled plots, which had greater biomass and vegetative cover (discussed below). Greater precipitation totals corresponded to greater sediment loss in compacted $\left(R^{2}=0.69\right)$, and ST $\left(R^{2}=0.75\right)$ treatments, but there was weak correlation $\left(R^{2}=0.32\right)$ in the DT treatment. Also, higher peak rainfall intensity corresponded to greater sediment loss in compacted $\left(R^{2}=0.64\right)$ and ST $\left(R^{2}=0.64\right)$ treatments, but there was no relationship in DT. This was likely due to a greater capacity for infiltrating water in DT soil, resulting in a very flat response curve. Consistent with our results, several studies also showed that intensity influences the type of sediment lost (Jennings et. al 1987; Parsons and Stones 2006; McIsaac and Mitchell 1992).

At Piedmont 2, erosion was reduced with tillage in 4 of the 13 events, and reduced during the entire monitoring period by $60 \%$ to $76 \%$ (table 3 ). There were no statistical differences between DT and DT+Com except for the last storm. There was little relationship between the amount of precipitation and sediment loss at Piedmont 2. However, greater peak rainfall intensity corresponded to greater sediment loss in the compacted treatment $\left(R^{2}=0.72\right)$.

Total sediment losses were reduced at both sites with tillage, which was closely related 
to the reduction in RV. The incorporation of $5 \mathrm{~cm} \mathrm{(2} \mathrm{in)} \mathrm{of} \mathrm{compost} \mathrm{did} \mathrm{not} \mathrm{have} \mathrm{any}$ impact on sediment loss, similar to the RV results. While others have demonstrated that rainfall intensity influences erosion rates under simulated conditions (Jennings et al. 1987; McIsaac and Mitchell 1992; Parsons and Stone 2006), we often found weak relationships, particularly for the tilled soils because they generated so little runoff.

Bulk Density and Infiltration Rate. Samples taken after compaction had an average BD of close to $1.5 \mathrm{~g} \mathrm{~cm}^{-3}(93.6 \mathrm{lb}$ $\left.\mathrm{ft}^{-3}\right)$ in the upper $15 \mathrm{~cm}$ (5.9 in) at both sites (table 4). Other studies related to construction operations also reported similar values for soil with a significant amount of clay (Alberty et al. 1984; McNabb 1994; Yang and Zhang 2011). At Piedmont 1, tillage reduced soil $\mathrm{BD}$ to 1.35 and $1.25 \mathrm{~g} \mathrm{~cm}^{-3}$ $\left(84.3\right.$ and $\left.78 \mathrm{lb} \mathrm{ft}^{-3}\right)$ for ST and DT, respectively, five months after site establishment. At Piedmont 2, tillage reduced BD to 1.02 and $0.66 \mathrm{~g} \mathrm{~cm}^{-3}\left(63.7\right.$ and $\left.41.2 \mathrm{lb} \mathrm{ft}^{-3}\right)$ for DT and $\mathrm{DT}+\mathrm{Com}$, respectively, seven months after site establishment. Numerous studies have documented a decrease in $\mathrm{BD}$ as a result of tillage in agricultural settings (Chen et al. 2010; Islam et al. 1994). There were no effects of mower traffic on bulk density.

The compacted treatment had relatively low IR of 2.1 and $0.9 \mathrm{~cm} \mathrm{~h}^{-1}(0.8$ and 0.35 in $\mathrm{hr}^{-1}$ ) at Piedmont 1 and 2, respectively (table 5). In contrast, the tillage treatments improved the IR from 19.8 to $33.3 \mathrm{~cm} \mathrm{~h}^{-1}$ (7.8 to 13.1 in $\left.\mathrm{hr}^{-1}\right)$. The depth of tillage, the addition of compost, or mower traffic did not affect IR. We do note that when using a single-ring apparatus, the potential lateral flow of infiltrating water below the ring may increase the apparent IR on unsaturated soils. Lateral flow toward drier areas of the soil pulls water from the surface towards areas outside the ring. Thus, the estimates of the steady IR may be somewhat larger than those expected for natural storm. To minimize the effect of lateral flow in our data, a correction factor was used according to the CSI manual. However, the measurements do demonstrate the relative effects of the tillage treatments compared to the compacted soil. An infiltration survey by Yang and Zhang (2011) found similarly low IR in urban areas, $6.3 \mathrm{~cm} \mathrm{~h}^{-1}\left(2.5{\left.\text { in } \mathrm{hr}^{-1}\right)}^{-1}\right.$ to less than $0.1 \mathrm{~cm} \mathrm{~h}^{-1}\left(0.04 \mathrm{in} \mathrm{hr}^{-1}\right)$. Other studies have also shown low infiltration due to compaction (Siyal 2002; Woltemade 2010). Haynes et al. (2013) found that IRs were less

\section{Table 4}

Bulk density $\left(\mathrm{g} \mathrm{cm}^{-3}\right)$ at both sites five to seven months after site establishment.

\begin{tabular}{lll}
\hline Treatment & Piedmont 1 & Piedmont 2 \\
\hline Compacted & $1.49 \mathrm{a}$ & $1.48 \mathrm{a}$ \\
Shallow till & $1.35 \mathrm{~b}$ & - \\
Deep till & $1.25 \mathrm{~b}$ & $1.02 \mathrm{~b}$ \\
Deep till + compost & - & $0.66 \mathrm{c}$ \\
\hline
\end{tabular}

Note: Means followed by the same letter within a column are not statistically different $(p=0.05)$.

\section{Table 5}

Infiltration rates $\left(\mathrm{cm} \mathrm{h}^{-1}\right)$ at both sites five to seven months after site establishment.

\begin{tabular}{lcc}
\hline Treatment & Piedmont 1 & Piedmont 2 \\
\hline Compacted & $2.1 \mathrm{~b}$ & $0.9 \mathrm{~b}$ \\
Shallow till & $20.8 \mathrm{a}$ & - \\
Deep till & $21.8 \mathrm{a}$ & $19.8 \mathrm{a}$ \\
Deep till + compost & - & $33.3 \mathrm{a}$ \\
\hline
\end{tabular}

Note: Means followed by the same letter within a column are not statistically different $(p=0.05)$.

than $0.1 \mathrm{~cm} \mathrm{~h}^{-1}\left(0.04 \mathrm{in}^{-1}\right)$ in similar soil compacted by truck traffic. At an agricultural site, Lipiec (2006) measured a 61\% increase in infiltration after tillage, which is comparable though somewhat less than what we observed.

Plant Growth. At Piedmont 1, five months after site establishment, tillage had improved grass growth (table 6). The shoot mass was nearly doubled with tillage, and grass coverage improved from $42 \%$ in compacted plots compared to $62 \%$ and $56 \%$ for ST and DT, respectively. No vegetation data were collected at Piedmont 2, but photographs taken three months after site establishment illustrate that there was a strong grass response to tillage and compost compared to the compacted plots (figure 1).

At Piedmont 1, five months after site establishment, in depths of 0 to $15 \mathrm{~cm}$ (0 to 5.9 in), the root density was greater in DT compared with both compacted and ST (table 7). At the 15 to $30 \mathrm{~cm}$ (5.9 to $11.8 \mathrm{in}$ ) depth, ST and DT both increased root density compared with the compacted soil. Consistent with these results, Grzesiak et al. (2002) showed that soil compaction is one of the most important factors of reducing root system development. Varsa et al. (1997) found that tillage caused greater depth of rooting in the profile. In general, the tilled treatments had much better grass establishment. Good vegetation establishment plays an important role in controlling RV and sediment loss by stabilizing the soil (Marques et al. 2007; Pan and Shangguan 2006). Pan and Shangguan (2006) found that soils with increasing vegetative cover $(35 \%, 45 \%, 65 \%$, and $90 \%)$ reduced runoff by $14 \%$ to $25 \%$ and sediment loss by $81 \%$ to $95 \%$ compared to bare soil.

\section{Summary and Conclusions}

Postconstruction soils often have limited infiltration and greater runoff rates during storm events. Tillage mechanically breaks up the soil, immediately adding porosity for rapid transfer of water through the soil profile. Both deep and shallow tillage treatments reduced runoff during the first four months after site establishment when the grass was being established, and there was some evidence that deeper tillage provided increased rainfall capture capacity. Deep tillage resulted in substantial infiltration, $87 \%$ to near $100 \%$ of precipitation, during all storm events compared to as low as $19 \%$ in the compacted soils. The results from this study indicate that when tillage is implemented on a modest slope, a large increase in infiltration and corresponding reduction in soil loss can result during the vegetation establishment phase. This study explored one way to mitigate urban stormwater volume problems. By increasing the IR through tillage and a healthy vegetative cover, runoff from grassed areas can be reduced substantially, in turn reducing volumes in the stormwater management system. In fact, the IRs we measured suggest that these areas may be able to infiltrate some of the runoff from adjacent impervious areas as well, assuming the high IRs are maintained over time. Aside from periodic mowing, we did not determine the effect of additional traffic on the IR, so we can only speculate that the effect of tillage on 


\section{Table 6}

Dry shoot mass and grass coverage at Piedmont 1, five months after site establishment.

\begin{tabular}{lll}
\hline Treatment & Shoot mass $\left(\mathbf{k g ~ h a}^{-\mathbf{1}}\right)$ & Grass cover $(\%)$ \\
\hline Compacted & $946 \mathrm{~b}$ & $42 \mathrm{~b}$ \\
Shallow till & $1,597 \mathrm{a}$ & $62 \mathrm{a}$ \\
Deep till & $1,566 \mathrm{a}$ & $56 \mathrm{a}$ \\
\hline
\end{tabular}

Note: Means followed by the same letter within a column are not statistically different $(p=0.05)$.

\section{Figure 1}

Plots at Piedmont 2 after three months, showing grass response to compacted (on the right), tillage alone (center), and part of the tillage + compost plot (on the far left end). Note that there were two runoff collection bins for each plot, one from the mowed half and one from the hand trimmed half.

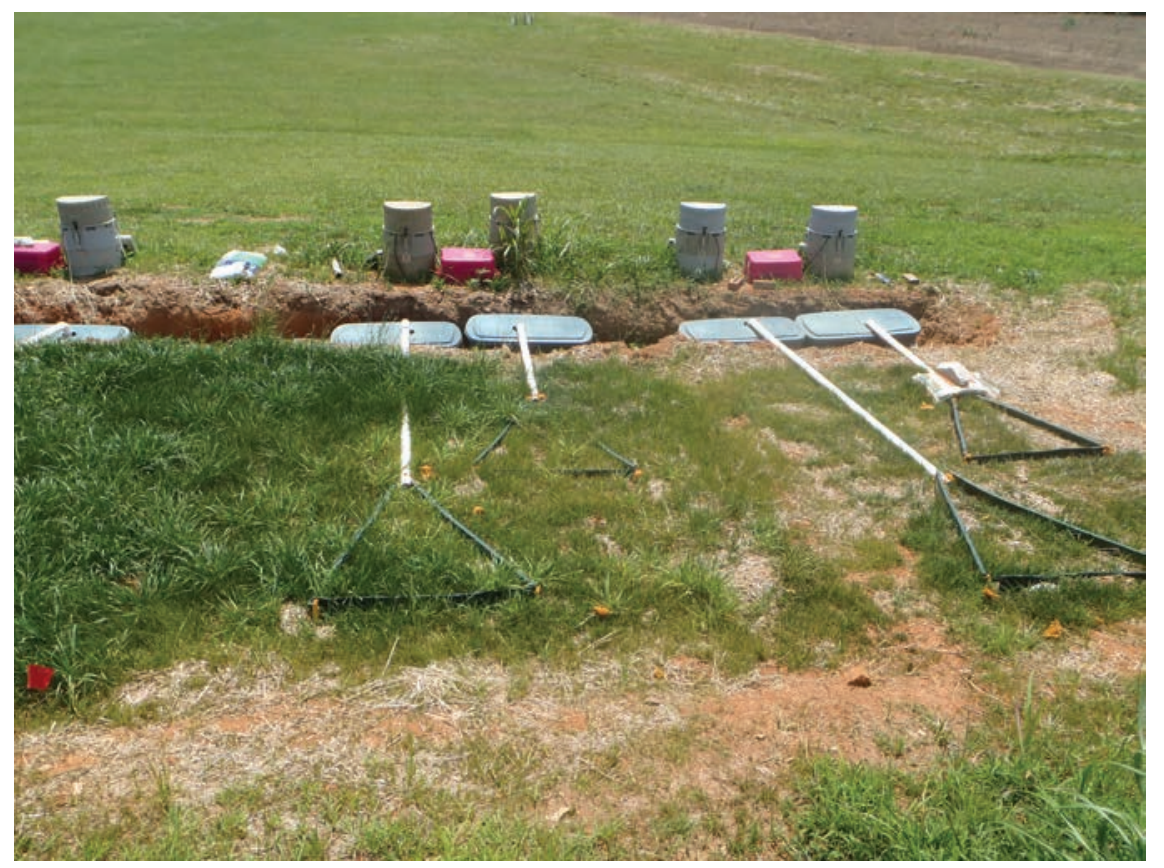

\section{Table 7}

Root density at Piedmont 1, five months after site establishment.

\begin{tabular}{lll}
\hline & Root density $\left(\mathbf{k g ~ m}^{-\mathbf{3}}\right)$ \\
\cline { 2 - 3 } Treatment & $\mathbf{0}$ to $\mathbf{1 5} \mathbf{~ c m}$ & $\mathbf{1 5}$ to $\mathbf{3 0} \mathbf{~ c m}$ \\
\hline Compacted & $0.43 \mathrm{~b}$ & $0.01 \mathrm{~b}$ \\
Shallow till & $0.56 \mathrm{~b}$ & $0.18 \mathrm{a}$ \\
Deep till & $1.07 \mathrm{a}$ & $0.21 \mathrm{a}$ \\
\hline
\end{tabular}

Note: Means followed by the same letter within a column are not statistically different $(p=0.05)$. long-term IR in grassed areas would remain as long as they received minimal traffic.

\section{References}

Alberty, C.A., H.M. Pellett, and D.H. Taylor. 1984. Characterization of soil compaction at construction sites and woody plant response. Journal of Environmental Horticulture 2(2):48-53.

Bartens, J., S.D. Day, J.R. Harris, J.E. Dove, and T.M. Wynn. 2008. Can urban tree roots improve infiltration through compacted subsoils for stormwater management? Journal of Environmental Quality 37(6):2048-57.

Batey, T., and D.C. McKenzie. 2006. Soil compaction: Identification directly in the field. Soil Use and Management 22(6):123-131.

Bazzoffi, P., S. Pellegrini, A. Rocchini, M. Morandi, and O. Grasselli. 1998. The effect of urban refuses compost and different tractors tires on soil physical properties, soil erosion and maize yield. Soil and Tillage Research 48:275-286.

Booth, D.B., and C.R. Jackson. 1997. Urbanization of aquatic systems: Degradation thresholds, stormwater detection, and the limits of mitigation. Journal of the American Water Resources Association 33:1077-1090.

Bouma, J., and L.W. Dekker. 1978. A case study on infiltration into dry clay soil I. morphological observations. Geoderma 20(1):27-40.

Brown, V.L. 2012. Establishing and Maintaining Enhanced Infiltration on Compacted Construction Site Subsoils Through Shallow and Deep Tillage with Soil Amendments. Master's thesis, North Carolina State University, Raleigh, North Carolina.

Chen, G., and R.R. Weil. 2010. Penetration of cover crop roots through compacted soils. Plant and Soil 331(1):31-43.

Clesceri, L.S., A.E. Greenberg, and A.D. Eaton. 1998. Standard methods for the examination of water and wastewater. 20th ed. Washington, DC: American Public Health Association. American Water Works Association. Water Environmental Federation 3-37-43.

Craul, P.J. 1994. In Urban Soils:An Overview and Their Future in Landscape Below Ground, eds. G.W. Watson and D. Neely. Savoy, IL: International Society of Arboriculture.

Curtis, M.J., and V.P. Claassen. 2007. Using compost to increase infiltration and improve the revegetation of a decomposed granite roadcut. Journal of Geotechnical and Geoenvironmental Engineering 133(2):215-8.

Gee, G.W., and J.W. Bauder. 1986. Particle-size analysis in methods of soil analysis, Part 1, monograph 9, Second Edition. Madison, WI: American Society of Agronomy.

Gilman, E.F. 1987. Effect of soil compaction and oxygen on vertical and horizontal root distribution. Journal of Environmental Horticulture 5(1):33-36.

Gregory, J., M. Dukes, P. Jones, and G. Miller. 2006. Effect of urban soil compaction on infiltration rate. Journal of Soil and Water Conservation 61(3):117-124. 
Grzesiak, S., M.T. Grzesiak, W. Filek, T. Hura, and J. Stabryla. 2002. The impact of different soil moisture and soil compaction on the growth of triticale root system. Physiologiae Plantarum 24(3):331-342.

Haynes, M.A., R.A. McLaughlin, and J.L. Heitman. 2013. Comparison of methods to remediate compacted soils for infiltration and vegetative establishment. Open Journal of Soil Science 3:225-234.

Hino, M., K. Fujita, and H. Shutto. 1987. A laboratory experiment on the role of grass for infiltration and runoff processes. Journal of Hydrology 90(3):303-25.

Houlbrooke, D.J., E.R. Thom, R. Chapman, and C.D.A McLay. 1997. A study of the effects of soil bulk density on root and shoot growth of different ryegrass lines. New Zealand Journal of Agricultural Research 40(4):429-435.

Isikwue, M.O., and S.A. Adakole. 2010. Effect of tillage and soil cover on soil erosion in the lower Benue River Basin of Nigeria, 335-345. Makurdi, Nigeria: Department of Agricultural and Environmental Engineering, University of Agriculture.

Islam, M.S., V.M. Salokhe, C.P. Gupta, and M. Hoki. 1994. Effects of PTO-powered disk tilling on some physical properties of Bangkok clay soil. Soil and Tillage Research 32(2):93-104.

Jennings, G.D., A.R. Jarrett, and J.R. Hoover. 1987 Simulated rainfall duration and sequencing affect soil loss. Transactions of the American Society of Agricultural Engineers 30(1):158-165.

Kozlowski, T.T. 1999. Soil compaction and growth of woody plants. Scandinavian Journal of Forest Research 14:596-619.

Lipiec, J., J. Kuś, A. Słowińska-Jurkiewicz, and A. Nosalewicz. 2006. Soil porosity and water infiltration as influenced by tillage methods. Soil and Tillage Research 89(2):210-220.

Marques, M.J., R. Bienes, L. Jiménez, and R. PérezRodríguez. 2007. Effect of vegetal cover on runoff and soil erosion under light intensity events. Rainfall simulation over USLE plots. Science of the Total Environment 378(1-2):161-165.

McIsaac, G., and J. Mitchell. 1992. Temporal variation in runoff and soil loss from simulated rainfall on corn and soybeans. Transactions of the American Society of Agricultural Engineers 35(2):465-472.

McNabb, D.H. 1994. Tillage of compacted haul roads and landings in the boreal forests of Alberta, Canada. Forest Ecology and Management 66(1):179-94.

NCDOT (North Carolina Department of Transportation). 2008. Erosion and Sediment Control - Special Provisions section. http://www.ncdot.gov/doh/ operations/dp_chief_eng/roadside/soil_water/ special_provisions/.

Ogden, C.B., H.M. Van Es, and R.R. Schindelbeck. 1997. Miniature rain simulator for field measurement of soil infiltration. Soil Science Society of America Journal 61(4):1041-1043
Olson, N.C., J.S. Gulliver, J.L. Nieber, and M. Kayhanian. 2013. Remediation to improve infiltration into compact soil. Journal of Environmental Management 117:85-95.

Pan, C., and Z. Shangguan. 2006. Runoff hydraulic characteristics and sediment generation in sloped grassplots under simulated rainfall conditions. Journal of Hydrology 331(1):178-185.

Parsons, A.J., and P.M. Stone. 2006. Effects of intra-storm variations in rainfall intensity on interrill runoff and erosion. Catena 67(1):68-78.

Randrup, T.B., and K. Dralle. 1997. Influence of planning and design on soil compaction in construction sites. Landscape and Urban Planning 38(1):87-92

Rogers, J.S., and C.E. Carter. 1987. Soil core sampling for hydraulic conductivity and bulk density. Soil Science Society of America Journal 51(5):1393-1394.

Schafer-Landefeld, L., R. Brandhuber, S. Fenner, H.-J. Koch, and N. Stockfisch. 2004. Effects of agricultural machinery with high axle load on soil properties of normally managed fields. Soil and Tillage Research 75:75-86.

Shestak, C.J., and M.D. Busse. 2005. Compaction alters physical but not biological indices of soil health. Soil Science Society of America Journal 69:236-246.

Siyal,A.G., F.C. Oad, M.A. SamoZia-Ul-Hassan, and N.L. Oad 2002. Effect of compactions on infiltration characteristics of soil. Asian Journal of Plant Sciences 1(1):3-4.

Varsa, E.C., S.K. Chong, J.O. Abolaji, D.A. Farquhar, and FJ. Olsen. 1997. Effect of deep tillage on soil physical characteristics and corn (Zea mays L.) root growth and production. Soil and Tillage Research 43(3-4):219-28.

Violin, C.R., P. Cada, E.B. Sudduth, B.A. Hassett, D.L. Penrose, and E.S. Bernhardt. 2011. Effects of urbanization and urban stream restoration on the physical and biological structure of stream ecosystems. Ecological Applications 21:1932-1949.

Vogt, K.A., and H. Persson. 1991. Measuring growth and development of roots. In Techniques and Approaches in Forest Tree Ecophysiology, eds. J.P. Lassoie and T.M Hinckley, 477-501. Boca Raton, FL: CRS Press.

Woltemade, C.J. 2010. Impact of residential soil disturbance on infiltration rate and stormwater runoff. Journal of the American Water Resources Association 46(4):700.

Yang, J., and G. Zhang. 2011. Water infiltration in urban soils and its effects on the quantity and quality of runoff. Journal of Soils and Sediments 11(5):751-61. 